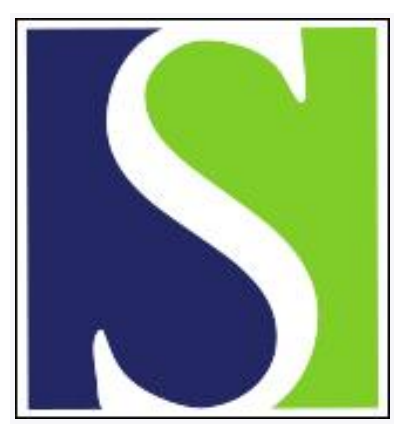

Scand J Work Environ Health 1976;2(1):90-105

https://doi.org/10.5271/sjweh.2828

Issue date: 1976

Turnover and health selection among foundry workers.

by Koskela R-S, Luoma K, Hernberg S

Key terms: cohort study; foundry worker; health selection; questionnaire; questionnaire study; retrospective cohort study; turnover

This article in PubMed: www.ncbi.nlm.nih.gov/pubmed/968469

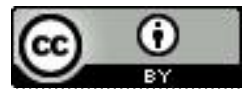




\title{
Turnover and health selection among foundry workers
}

\author{
by RIITTA-SISKO KOSKELA, M.Sc., KALEVI LUOMA, B.Sc., and \\ SVEN HERNBERG, M.D.
}

\begin{abstract}
KOSKELA, R.-S., LUOMA, K. and HERNBERG, S. Turnover and health selection among foundry workers. Scand. $j$. work environ. \& health 2 (1976): suppl. 1, 90105. The quantity, reasons, and health selection involved in labor turnover were studied with the use of questionnaires and employers' records. The basic material was the personnel of 20 representative foundries. The turnover in 1950-1972 was estimated from a sample of 588 workers. The causes and health selection were studied with questionnaires put to the 1,789 current employees (91\% response), the 493 foundrymen who had left after at least 5 years of exposure (the 5-year-plus men, $71 \%$ response) and 424 of those who had left after less than 1 year of exposure (the 1-year-minus men, $55 \%$ response). The men were asked to describe their present and earlier work at the foundry, the nature and duration of their exposure, diagnosed lung and heart diseases, and chronic bronchitis and angina pectoris and to assess their present and former state of health and work capacity. The disability analysis was based on a sample of 2,834 men whose data were taken from the Social Insurance Register. The disability findings were compared to expected values based on the Finnish male population. Turnover proved to be rapid; short periods of employment predominated. The major reasons for leaving were poor work conditions, physically demanding work, low pay, and poor health. The turnover was fastest in dusty occupations. Relatively more exfoundrymen, both 5-year-plus and 1-year-minus, than current employees felt their health and/or work capacity to be poor. More of the older men in the 5-year-plus group than men of the same age in the current group had chronic bronchitis and diagnosed lung disorders. Both the 5-year-plus and the 1-year-minus exfoundrymen had relatively more diagnosed heart disorders than did the current employees. The disability prevalences of the foundrymen in any category of diseases did not exceed the expected values based on the male population. The overall findings indicate early health selection prior to pensionable disability and/or death.
\end{abstract}

Key words: foundry workers, turnover, health selection, questionnaire study, retrospective cohort study.

Several studies on physically demanding work have revealed morbidity and mortality figures lower than the value that could be expected based on the general population. This phenomenon has been found particularly in mortality studies and is called "the healthy worker effect" (3,

1 Department of Epidemiology and Biometry, Institute of Occupational Health, Helsinki, Finland.

Reprint requests to: Ms. Riitta-Sisko Koskela, Institute of Occupational Health, Haartmaninkatu 1, FIN-00290 Helsinki 29, Finland.
9 , 11). A similar selection mechanism is assumed to be at work in morbidity studies $(1,2)$.

Few empirical studies have been made on the health of workers terminating their employment. A study on cotton workers indicated that their high turnover was due largely to reasons of health, and morbidity figures for the factories were reduced because persons with poor health left (4). A 3-year follow-up of dock workers revealed that those who left were clearly less healthy than those who stayed (2). However some authors consider the 
reason for the low morbidity found in such studies to be that physically demanding work protects the worker from illness (13).

Rapid employee turnover hampers the study of occupational health risks because of the health selection involved, and the measurement of the effect of work on health is impeded by the number of levels of the effect. The present study relates specifically to health selection. It starts from the assumption that no single level of the effect of work on health can, by itself, give a true general picture in a surveillance study and, in a sector with high labor turnover, soft levels may be as explanatory as hard levels.

Our aim was to obtain an overall picture of the effect of work on health by analyzing its different levels (i.e., mortality, disability, termination of employment because of poor health or other reasons, and health status of present employees) simultaneously in the same material.

The plan for the epidemiologic part of the Finnish Foundry Project, of which this study is a part, is presented in another article (5). The mortality and health of the current employees ${ }^{2}$ are also described elsewhere $(6,7,9)$. This paper deals with the differences of health and work capacity between workers whose foundry employment terminated and those who were still at work.

\section{MATERIAL AND METHODS}

The material from which the subjects for this labor turnover study were taken comprised the 15,401 employees hired between 1 January 1950 and 31 December 1972 by the 20 foundries selected for the epidemiologic part of the Finnish Foundry Project (5). The subjects were classified according to exposure times as shown in table 1. For the most part periods of employment were short. Only $8 \%$ lasted 5 years or more.

For a closer quantitative analysis of the turnover among foundry workers, we formed a sample of 588 men with an equal number from each exposure time class, i.e., 1 out of every 67 from the 11,000 in

2 In this article "current employees or workers" refers to those men employed by the foundries on 31 December 1972. the under-1-year class, 1 out of every 13 from the 1,900 in the 1-to-3-year class, 1 out of every 4 from the 600 in the 3-to5 -year class, and 1 out of every 9 from the 1,300 in the over-5-year class.

\section{Questionnaire study}

The reasons for the turnover were studied by means of a questionnaire sent to all 493 persons whose employment terminated after they had worked for at least 5 years ("the 5-year-plus men") and those 424 persons who left after less than 1 year ("the 1-year-minus men"). The latter group comprised one-twentieth of all those whose employment terminated after less than 1 year, i.e., one-half of the exfoundrymen in this exposure class still alive who had been included in the mortality study (9). These two groups were selected as representing extremes of exposure.

The results of the questionnaire were compared to the data from a preliminary questionnaire put to all the 1,789 workers employed by the 20 foundries on 31 December 1972 and to the data on the 1,000 men selected for a health examination $(6,9)$. Table 2 presents the objects and types of questions used in the three questionnaires.

A total of $1,631(91 \%)$ of the 1,789 current foundrymen replied to the preliminary questionnaire and 1,576 of the replies were usable. Of the 1,000 requested to undergo a health examination (minimum exposure 4.2 years), $931(93 \%$ ) did so. Of the 4935 -year-plus exfoundrymen $348(71 \%)$ replied and 338 replies were usable, whereas $233(55 \%)$ of the 4241 -

Table 1. Employees hired between 1950 and 1972 by duration of employment (exposure time).

\begin{tabular}{lrr}
\hline $\begin{array}{l}\text { Duration of } \\
\text { employment } \\
\text { (years) }\end{array}$ & $\begin{array}{l}\text { Number of } \\
\text { employees }\end{array}$ & $\%$ \\
\hline$\leq 0.9$ & 11,455 & 74 \\
$1.0-2.9$ & 2,084 & 14 \\
$3.0-4.9$ & 629 & 4 \\
$5.0-9.9$ & 651 & 4 \\
$10.0-14.9$ & 301 & 2 \\
$\geq 15.0$ & 281 & 100 \\
\hline Total & 15,401 & \\
\hline
\end{tabular}


Table 2. Objects and types of questions used in the three questionnaires presented to the current and former foundrymen.

\begin{tabular}{|c|c|c|}
\hline Foundrymen & Object of question & $\begin{array}{l}\text { Type of } \\
\text { question }\end{array}$ \\
\hline \multirow{4}{*}{$\begin{array}{l}\text { Current (pre- } \\
\text { liminary ques- } \\
\text { tionnaire) and } \\
\text { former }\end{array}$} & $\begin{array}{l}\text { History and description of subject's work at foundry; all } \\
\text { previous occupations and their duration }\end{array}$ & Open-ended \\
\hline & $\begin{array}{l}\text { Subject's own assessment of diseases caused by the work in } \\
\text { the foundry }\end{array}$ & Open-ended \\
\hline & $\begin{array}{l}\text { Subject's own assessment of present work capacity in } \\
\text { comparison to that at his best working age ( } 0 \text { - to 10-point } \\
\text { scale, } 10 \text { being the best) }\end{array}$ & Classified \\
\hline & $\begin{array}{l}\text { Subject's own assessment of present helath (fully healthy, } \\
\text { satisfactory, no complaints, could be better, ill) }\end{array}$ & Classified \\
\hline \multirow{4}{*}{$\begin{array}{l}\text { Current } \\
\text { (health } \\
\text { examination) } \\
\text { and former }\end{array}$} & $\begin{array}{l}\text { Previously diagnosed diseases of the heart and respiratory } \\
\text { system }\end{array}$ & Classified \\
\hline & Angina pectoris and chronic bronchitis $(12,15)$ & Classified \\
\hline & Reason for latest visit to a doctor & Open-ended \\
\hline & $\begin{array}{l}\text { Subject's own assessment of daily duration of uncomfortable } \\
\text { work postures (18) }\end{array}$ & Classified \\
\hline \multirow[t]{4}{*}{ Former } & Reasons for termination of foundry employment & $\begin{array}{l}\text { Classified } \\
\text { (order of } \\
\text { importance } \\
\text { open-ended) }\end{array}$ \\
\hline & Occupation taken up afier leaving foundry work & Open-ended \\
\hline & Reascns for choosing new occupation & $\begin{array}{l}\text { Classified } \\
\text { (order of } \\
\text { importance } \\
\text { open-ended) }\end{array}$ \\
\hline & $\begin{array}{l}\text { Subject's own assessment of work capacity at time of leaving } \\
\text { foundry work in comparison with that at his best working } \\
\text { age ( } 0 \text { - to } 10 \text {-point scale, } 10 \text { being the best) }\end{array}$ & Classified \\
\hline
\end{tabular}

Table 3. Cumulative response $(\%)$ to the preliminary and former-worker questionnaires.

\begin{tabular}{lccc}
\hline Foundrymen & $\begin{array}{c}\text { Question- } \\
\text { naire }\end{array}$ & $\begin{array}{c}\text { 1st } \\
\text { reminder }\end{array}$ & $\begin{array}{c}\text { 2nd } \\
\text { reminder }\end{array}$ \\
\hline $\begin{array}{l}\text { Current } \\
\begin{array}{l}\text { Former } \\
<1-\text { year } \\
\text { exposure }\end{array}\end{array}$ & 66 & 80 & 91 \\
$\begin{array}{l}\geq \text { 5-year } \\
\text { exposure }\end{array}$ & 43 & 50 & 55 \\
\hline
\end{tabular}

year-minus men replied and 229 of their replies could be used. The response to the questionnaires and two reminders is shown in table 3 .

The participation percentage for both the preliminary questionnaire and the health examination of current workers was excellent. Most of the nonresponse was due to termination of employment between the time the material for the study was prepared (31 December 1972) and the times of the actual questionnaire and health examination (March 1973 - May 1974).

The reasons for the nonresponse of former employees are given in table 4 . The reply percentage of the 5-year-plus exfoundrymen was satisfactory $(75 \%$ after the omission of nonfoundrymen and those who died after the questionnaire was sent out). That of the 1-year-minus men was low.

Table 5 shows the percentages of those who did not reply. The nonresponse of the 5-year-plus men was fairly evenly distributed by age class, whereas the nonresponse of the 1-year-minus men decreased with age.

\section{Disability}

The disability analysis covered all the 1,233 foundrymen whose exposure had 
Table 4. Exfoundrymen responding and not responding to the questionnaire and the reasons Ior nonresponse.

\begin{tabular}{|c|c|c|c|c|c|}
\hline & \multicolumn{2}{|c|}{$<1$-year exposure } & \multicolumn{3}{|c|}{$\geq 5$-year exposure } \\
\hline & Number & $\%$ & Number & $\%$ & \\
\hline $\begin{array}{l}\text { Replied } \\
\text { Did not reply }\end{array}$ & $\begin{array}{l}233 \\
191\end{array}$ & $\begin{array}{l}55.0 \\
45.0\end{array}$ & $\begin{array}{l}348 \\
145\end{array}$ & $\begin{array}{l}70.6 \\
29.4\end{array}$ & \\
\hline dead & 3 & 0.7 & 16 & & 3.2 \\
\hline address unknown & 21 & 5.0 & 15 & & 3.0 \\
\hline abroad & 12 & 2.8 & 15 & & 3.0 \\
\hline not foundrymen & 7 & 1.7 & 7 & & 1.4 \\
\hline reason unknown & 148 & 34.9 & 92 & & 18.7 \\
\hline Total & 424 & 100.0 & 493 & 100.0 & \\
\hline
\end{tabular}

lasted at least 5 years, all 629 who had done foundry work for 3 to 5 years, and 972 of the persons, i.e., every tenth, whose exposure had lasted less than 1 year. The subjects in the sample were the same as those taken from the corresponding exposure time classes for the mortality analysis (9). The disability data were taken from the Social Insurance Register.

\section{Exposure}

In classifying the employees by occupation, we used both the worker's last or current occupation in the foundry and that in which he had been engaged during most of his time in the foundry. The ratios between occupations noted as last (current) occupations and main occupations did not differ substantially, and we generally classified the men according to their main occupations.

The employees were also categorized according to the carbon monoxide (CO) exposure (6) and dust exposure (7) of their main occupations.

Exposure time was measured in the following two ways: (a) from exposure times taken from employers' records and (b) from those notified by the employees. Since exposure time according to the records denoted only time spent in the one foundry, that notified by the employees must be regarded as a truer measure of exposure.

The coverages of exposure times on the employers' records to those notified by the employees (percentage ratio of the former to the latter) and the average deviations between them in years are
Table 5. Percentages of nonrespondents per age class.

\begin{tabular}{|c|c|c|c|}
\hline \multirow[b]{2}{*}{ Age } & \multirow{2}{*}{$\begin{array}{c}\text { Current } \\
\text { foundrymen }\end{array}$} & \multicolumn{2}{|c|}{ Former foundrymen } \\
\hline & & $\begin{array}{l}<1 \text {-year } \\
\text { exposure }\end{array}$ & $\begin{array}{l}\geq 5 \text {-year } \\
\text { exposure }\end{array}$ \\
\hline $15-24$ & 20 & 50 & 50 \\
\hline $25-34$ & 11 & 48 & 32 \\
\hline $35-44$ & 6 & 45 & 26 \\
\hline $45-54$ & 6 & 45 & 38 \\
\hline $55-64$ & 7 & 31 & 26 \\
\hline $65-74$ & 9 & 11 & 33 \\
\hline Total & 10 & 45 & 31 \\
\hline
\end{tabular}

given in table 6 . The coverage was $83 \%$ for current employees and $74 \%$ for 5 -yearplus exfoundrymen. The average deviation in years increased with age.

Although the coverage for the exposure time classes was rather good on the whole, the coverage for the 1-year-minus men was only $17 \%$. Obviously the measurement error was very large in this group, particularly in the older age classes. The size of the average deviations in the older age classes may indicate that the smallness of the coverage was due to very wide deviations in a relatively small number of cases. We therefore calculated the percentages of cases in which the exposure time on employers' records was identical to that notified by the employee (table 7). This calculation showed that the exposure times measured in both ways were equal in roughly similar percentages in all the exposure classes. A closer analysis of the exposure time deviations in the under1-year class revealed that $79 \%$ of them were deviations of less than 2 years. 
Table 6. Coverages of exposure times on employers' records to those notified by employees (percentage of former to latter) and average deviation in years per age class.

\begin{tabular}{|c|c|c|c|c|c|c|}
\hline \multirow[b]{3}{*}{ Age (a) } & \multirow{2}{*}{\multicolumn{2}{|c|}{ Current foundrymen }} & \multicolumn{4}{|c|}{ Former foundrymen } \\
\hline & & & \multicolumn{2}{|c|}{$<1$-year exposure } & \multicolumn{2}{|c|}{$\geq 5$-year exposure } \\
\hline & $\begin{array}{c}\text { Average } \\
\text { coverage } \\
(\%)\end{array}$ & $\begin{array}{c}\text { Average } \\
\text { deviation } \\
\text { (a) }\end{array}$ & $\begin{array}{c}\text { Average } \\
\text { coverage } \\
(\%)\end{array}$ & $\begin{array}{c}\text { Average } \\
\text { deviation } \\
\text { (a) }\end{array}$ & $\begin{array}{c}\text { Average } \\
\text { coverage } \\
(\%)\end{array}$ & $\begin{array}{c}\text { Average } \\
\text { deviation } \\
\text { (a) }\end{array}$ \\
\hline $15-24$ & 80 & 1.0 & 59 & 0.3 & 93 & 0.4 \\
\hline $25-34$ & 86 & 1.2 & 36 & 0.7 & 83 & 1.5 \\
\hline $35-44$ & 84 & 2.2 & 20 & 2.0 & 82 & 1.9 \\
\hline $45-54$ & 85 & 3.1 & 15 & 2.6 & 69 & 4.4 \\
\hline $55-64$ & 79 & 5.5 & 4 & 10.2 & 72 & 4.0 \\
\hline$\geq 65$ & 93 & 2.2 & $\overline{7}$ & 7.6 & 56 & 8.5 \\
\hline Total & 83 & 2.8 & 17 & 2.1 & 74 & 3.1 \\
\hline
\end{tabular}

Table 7. Percentages of cases in which exposure time according to employers' records equaled that notified by the employee.

\begin{tabular}{|c|c|c|c|}
\hline \multirow[b]{2}{*}{ Age (a) } & \multirow{2}{*}{$\begin{array}{c}\text { Current } \\
\text { foundrymen }\end{array}$} & \multicolumn{2}{|c|}{ Former foundrymen } \\
\hline & & $\begin{array}{l}<1 \text {-year } \\
\text { exposure }\end{array}$ & $\begin{array}{l}\geq 5 \text {-year } \\
\text { exposure }\end{array}$ \\
\hline $15-24$ & 71 & 66 & 75 \\
\hline $25-34$ & 63 & 60 & 48 \\
\hline $35-44$ & 58 & 53 & 60 \\
\hline $45-54$ & 55 & 67 & 53 \\
\hline $55-64$ & 53 & 29 & 61 \\
\hline$\geq 65$ & 50 & 43 & 63 \\
\hline Total & 58 & 56 & 57 \\
\hline
\end{tabular}

\section{Methods of comparison}

No external control group was used for the study of health selection and labor turnover. Instead we compared the exposure time classes of the current and former foundrymen with one another to demonstrate the effect of foundry work on health.

The prevalences to be compared had to be standardized because of the differences in the age structures of the exposure time classes. The age distribution of the current workers who underwent the health examination was used as the standard.

The differences between the prevalences of the exposure classes were tested by the Mantel \& Haenszel method (10). The test statistic was $\chi^{2}$ with one degree of freedom. The age class differences were eliminated to the accuracy of a 10-year age class.

We analyzed the termination-of-employment rates, including death, for different occupations within the foundries by matching pairs of the same ages among the current and former foundrymen (living and dead). The same number of pairs was selected from each exposure time class (under 1 year, $1-2.9,3-4.9$, and 5 years and over). The occupational distributions of current and former workers thus obtained were then compared.

To treat the work capacity results we used linear regression, in which the changes in work capacity were analyzed as a function of age and exposure time.

The disability prevalence of the subjects was then compared with the age-specific disability prevalence of the male population of Finland at the same point in time (31 December 1972) (8).

\section{RESULTS}

\section{Background data on the foundrymen}

The age distributions of the current and former foundrymen clearly deviated (table 8). Among the former workers the mean age of the 1-year-minus men was the lowest; and that of the 5-year-plus men, the highest. However the latter group was similar in age distribution to the current foundry workers who underwent the health examination. 
The current workers and 5-year-plus former workers began their exposure at roughly the same ages (table 9). On the average the 1-year-minus men were younger at the start of their exposure.

The tradesmen who lasted the longest in foundry work on the average were the floor molders (18 years), machine molders (14 years), casters (14 years) and furnacemen (12 years), i.e., the most skilled. The floor molders and coremakers began foundry work at the youngest ages; and the general laborers, truck drivers, and fettlers, at the oldest.

Most of the exposure times of the current workers (all at work on 31 December 1972, regardless of when they began) occurred during the 1960s. Sixtyfour per cent of them began in 1960 or later, but a remarkable number $(18 \%)$ started foundry work before 1950 .

Among the former workers the median starting year was $1963 \quad\left(\mathrm{Q}_{0.25}=1957\right.$, $\left.\mathrm{Q}_{0.75}=1968\right)$ for the 1-year-minus men and $1954\left(Q_{0.25}=1951, Q_{0.75}=1960\right)$ for the 5-year-plus ones. Thirty-seven per cent of the 5-year-plus men began sometime between 1950 and 1954 - a period of exceptionally rapid expansion in the Finnish foundry industry. Only $9 \%$ of the current workers and $10 \%$ of the 1year-minus exfoundrymen began during this period.

The median end-of-exposure years of the former foundrymen were $1965\left(Q_{0.25}\right.$ $\left.=1962, Q_{0.75}=1970\right)$ for the 1-year-minus and $1969\left(Q_{0.25}=1963, Q_{0.75}=1972\right)$ for the 5-year-plus men.

The occupational distributions of the current and former foundrymen are given in table 10. General laborers were considerably more numerous, relatively speaking, among the former workers than among the current ones. The opposite was true for machine molders, furnacemen, and "others." Little difference was found in the occupational distributions of the former 5-year-plus men and the current workers; there were relatively more "others" among the current workers and relatively more casters and general laborers among the 5-year-plus men.

Table 8. Age distributions of the current and former foundrymen.

\begin{tabular}{|c|c|c|c|c|c|c|c|c|}
\hline \multirow{3}{*}{ Age (a) } & \multicolumn{4}{|c|}{ Current } & \multicolumn{4}{|c|}{ Former } \\
\hline & \multicolumn{2}{|c|}{$\begin{array}{l}\text { Preliminary } \\
\text { questionnaire }\end{array}$} & \multicolumn{2}{|c|}{$\begin{array}{c}\text { Health } \\
\text { examination }\end{array}$} & \multicolumn{2}{|c|}{$\begin{array}{l}<1 \text {-year } \\
\text { exposure }\end{array}$} & \multicolumn{2}{|c|}{$\begin{array}{l}\geq 5 \text {-year } \\
\text { exposure }\end{array}$} \\
\hline & Number & $\%$ & Number & $\%$ & Number & $\%$ & Number & $\%$ \\
\hline $15-24$ & 206 & 13.1 & 17 & 1.8 & 30 & 13.1 & 4 & 1.2 \\
\hline $25-34$ & 448 & 28.4 & 196 & 21.1 & 85 & 37.1 & 55 & 16.3 \\
\hline $35-44$ & 378 & 24.0 & 273 & 29.3 & 64 & 27.9 & 127 & 37.6 \\
\hline $45-54$ & 348 & 22.1 & 279 & 30.0 & 24 & 10.5 & 89 & 26.3 \\
\hline $55-64$ & 186 & 11.8 & 160 & 17.2 & 18 & 7.9 & 43 & 12.7 \\
\hline$\geq 65$ & 10 & 0.6 & 6 & 0.6 & 8 & 3.5 & 20 & 5.9 \\
\hline Total & 1,576 & 100.0 & 931 & 100.0 & 229 & 100.0 & 338 & 100.0 \\
\hline
\end{tabular}

Table 9. Means and standard deviations of exposure times and the ages at the start and end of exposure.

\begin{tabular}{|c|c|c|c|c|c|c|c|c|}
\hline \multirow{3}{*}{ Foundrymen } & \multicolumn{4}{|c|}{ Exposure according to } & \multirow{2}{*}{\multicolumn{2}{|c|}{$\begin{array}{l}\text { Age at start } \\
\text { of exposure }\end{array}$}} & \multirow{2}{*}{\multicolumn{2}{|c|}{$\begin{array}{l}\text { Age at end } \\
\text { of exposure }\end{array}$}} \\
\hline & \multicolumn{2}{|c|}{ Employers } & \multicolumn{2}{|c|}{ Employees } & & & & \\
\hline & Mean & $\mathrm{SD}$ & Mean & $\mathrm{SD}$ & Mean & SD & Mean & $\mathrm{SD}$ \\
\hline $\begin{array}{l}\text { Current } \\
\text { Former }\end{array}$ & 9.7 & 9.1 & 11.9 & 10.4 & 26.2 & 8.4 & 37.8 & 12.2 \\
\hline $\begin{array}{l}<1 \text {-year exposure } \\
\geq \text { 5-year exposure }\end{array}$ & $\begin{array}{l}0.5 \\
9.0\end{array}$ & $\begin{array}{l}0.2 \\
5.3\end{array}$ & $\begin{array}{r}2.6 \\
12.1\end{array}$ & $\begin{array}{l}6.5 \\
7.4\end{array}$ & $\begin{array}{l}25.0 \\
26.0\end{array}$ & $\begin{array}{l}8.4 \\
8.8\end{array}$ & $\begin{array}{l}28.3 \\
38.8\end{array}$ & $\begin{array}{r}9.6 \\
11.4\end{array}$ \\
\hline
\end{tabular}


Table 10. Occupational breakdown of current and former employees according to their main occupation in the foundries.

\begin{tabular}{|c|c|c|c|c|c|c|}
\hline \multirow{3}{*}{ Occupation } & \multirow{2}{*}{\multicolumn{2}{|c|}{ Current }} & \multicolumn{4}{|c|}{ Former } \\
\hline & & & \multicolumn{2}{|c|}{$<1$-year exposure } & \multicolumn{2}{|c|}{$\geq 5$-year exposure } \\
\hline & Number & $\%$ & Number & $\%$ & Number & $\%$ \\
\hline Floor molders & 126 & 8.0 & 28 & 12.2 & 30 & 9.0 \\
\hline Machine molders & 265 & 16.9 & 19 & 8.3 & 59 & 17.7 \\
\hline Coremakers & 111 & 7.1 & 13 & 5.7 & 22 & 6.6 \\
\hline Casters & 109 & 6.9 & 22 & 9.6 & 34 & 10.2 \\
\hline Ingot casters & 21 & 1.3 & 1 & 0.4 & 6 & 1.8 \\
\hline Fettlers & 360 & 22.9 & 50 & 21.8 & 71 & 21.3 \\
\hline Furnacemen & 173 & 11.0 & 9 & 3.9 & 41 & 12.3 \\
\hline Truck drivers & 44 & 2.8 & 4 & 1.8 & 10 & 3.0 \\
\hline Laborers & 92 & 5.9 & 60 & 26.2 & 28 & 8.4 \\
\hline Others & 271 & 17.2 & 23 & 10.0 & 33 & 9.9 \\
\hline Total & 1,572 & 100.0 & 229 & 100.0 & 334 & 100.0 \\
\hline
\end{tabular}

Altogether $48 \%$ of the 1-year-minus men, but only $29 \%$ of the 5-year-plus men and the current workers, were general laborers and fettlers. As could be expected, turnover was the highest among these least skilled groups.

To analyze the effect of dust on symptoms of the respiratory system (7), we classified the occupations according to their "dustiness." Forty-eight per cent of the

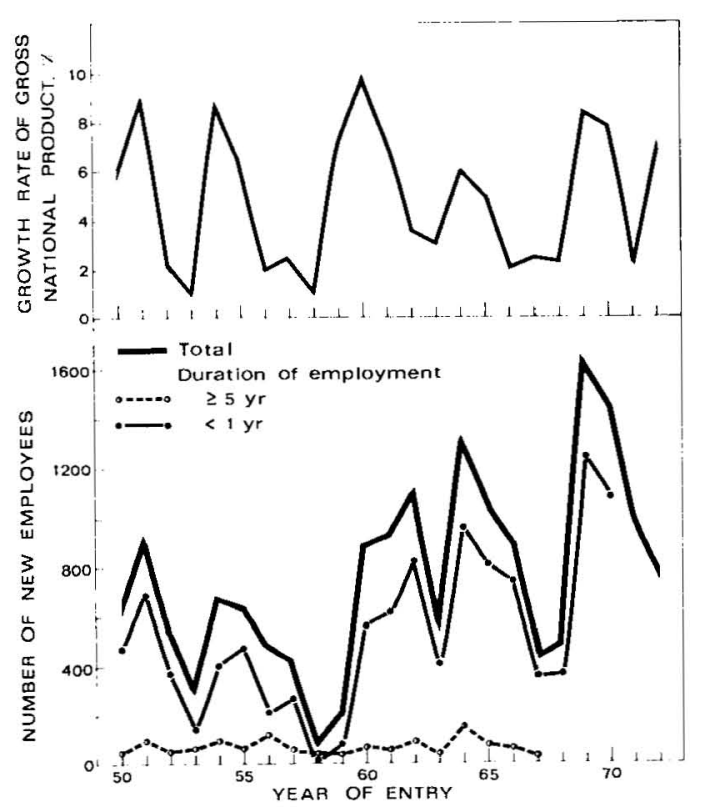

Fig. 1. New employees at foundries versus growth rate of gross national product. current and 5-year-plus former workers and $43 \%$ of the 1-year-minus men were in dusty occupations.

Casters and furnacemen were classed as being the most exposed to carbon monoxide (6). In all, $23 \%$ of the 5-yearplus men, $18 \%$ of the current workers, and $14 \%$ of the 1-year-minus men were in these two occupations. In this case the difference between the current workers and the 5-year-plus former workers was statistically significant $\left(\mathrm{p}<0.05, \chi^{2}\right.$ test),

\section{Rate of and reasons for turnover}

Fig. 1 shows estimates of the number of workers hired each year by the foundries included in this study. They were calculated from the 588-man sample and compared to the growth rate of the Finnish gross national product $(16,17)$. The number of new employees varied strongly with the business cycle, with no time lag, in the case of the short exposure classes. The variation was not so strong however for the employees who stayed longer.

About one-third $(31 \%)$ of the current employees had earlier been in agriculture or forestry, a fifth $(22 \%)$ in industry, and a tenth in the construction industry. Roughly the same distribution was found among the former employees (table 11). The occupations to which the exfoundrymen moved after leaving the foundries largely reflect changes in the occupational structure of Finland. They also reflect 
Table 11. Former occupations of exfoundrymen $(\%)$ and occupations to which they changed.

\begin{tabular}{|c|c|c|c|c|}
\hline \multirow[b]{2}{*}{ Former or new occupation } & \multicolumn{2}{|c|}{ Before entering } & \multicolumn{2}{|c|}{ After leaving } \\
\hline & $\begin{array}{l}<1 \text {-year } \\
\text { exposure }\end{array}$ & $\begin{array}{l}\geq 5 \text {-year } \\
\text { exposure }\end{array}$ & $\begin{array}{l}<1 \text {-year } \\
\text { exposure }\end{array}$ & $\begin{array}{l}\geq \text { 5-year } \\
\text { exposure }\end{array}$ \\
\hline
\end{tabular}

Agriculture, forestry

Construction

Foundry a

Other metal industry

Other industry

Transport, communication

Commerce

Office

Other services

Others

Not at work

\begin{tabular}{rc}
34 & 38 \\
11 & 16 \\
\hline 7 & - \\
13 & 3 \\
5 & 14 \\
- & 4 \\
0.5 & 1 \\
2 & 0.3 \\
8 & 2 \\
19 & 7 \\
& 15
\end{tabular}

$\begin{array}{rr}9 & 3 \\ 25 & 11 \\ 9 & 18 \\ 12 & 17 \\ 15 & 15 \\ 4 & 6 \\ 2 & 2 \\ 1 & 1 \\ 4 & 3 \\ 14 & 4 \\ 4 & 20\end{array}$

a Entry in this case refers only to the employees' first employment in a foundry; therefore only the foundrymen who moved on to another foundry are included.

changes in health, training, etc., due specifically to foundry work. In brief, whereas about one-third of all the foundrymen came from agriculture or forestry, roughly the same fraction of those whose employment terminated went on to another foundry or some other branch of the metal industry.

The termination-of-employment rate was the fastest among young workers in the 20 - to 24-year age class. Thereafter it fell steadily with age, but speeded up again in the 50- to 54-year age class particularly in its higher exposure time classes (fig. 2).

Pair comparison revealed that dusty occupations had a significantly faster termination rate than other work $(p<0.01$, $\chi^{2}$ test). The $\mathrm{CO}$ exposed occupations also had a higher rate than the others, but the difference was not significant.

Table 12 presents the reasons exfoundrymen gave for leaving foundry work, the most common being poor work conditions, physically demanding work, and low pay. The percentages in the table were calculated from all the usable replies of former workers. Those receiving a disability pension were not asked their reason for quitting because it was known. Disability pensioners accounted for $16 \%$ of the 5-year-plus men and $1 \%$ of the 1-year-minus men. Twenty-nine per cent of the 5-year-plus men and $7 \%$ of the 1-year-minus men left for reasons of poor health, either notified in their replies or given as a basis for their disability pensions.

Better work conditions and less physically demanding, more interesting, and better paid work were the most important reasons given for the choice of a new job (table 13). Many of those who went on to another foundry said they did so because it was the only kind of work they could get. These men included $31 \%$ of the 5-year-plus and $21 \%$ of the 1-yearminus men. Only $12 \%$ of both exposure groups gave the same reason for accepting a job not in a foundry.

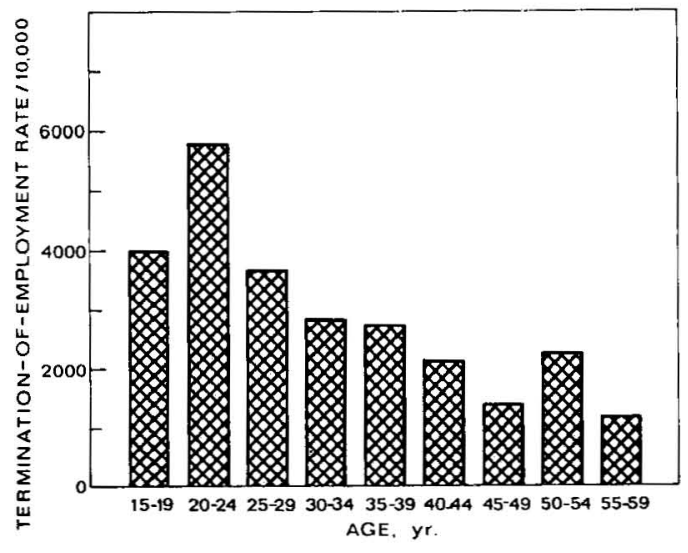

Fig. 2. Termination- of employment per 10,000 employees versus age. 
Table 12. Reasons notified by foundrymen for leaving foundry; each man was asked to mark three reasons.

\begin{tabular}{lcc}
\hline $\begin{array}{l}\text { Reason for leaving } \\
\text { foundry }\end{array}$ & $\begin{array}{c}<1 \text {-year } \\
\text { exposure } \\
(\% / 0)\end{array}$ & $\begin{array}{c}\geq 5 \text {-year } \\
\text { exposure } \\
(\% / 0)\end{array}$ \\
\hline Low pay & 37 & 26 \\
Poor conditions & 44 & 33 \\
Physically demanding & 44 & 33 \\
Illness & 6 & 13 \\
Uninteresting work & 28 & 15 \\
Poor prospects & 17 & 10 \\
Training & 11 & 3 \\
Friction at work & 10 & 11 \\
Family, housing & 14 & 16 \\
Others & 11 & 9 \\
\hline
\end{tabular}

Table 13. Reasons for choosing new job; each man was asked to mark three reasons.

\begin{tabular}{lcc}
\hline $\begin{array}{l}\text { Reason for choice } \\
\text { of a nzw job }\end{array}$ & $\begin{array}{c}<\text { 1-year } \\
\text { exposure } \\
(\%)\end{array}$ & $\begin{array}{c}\geq \text { 5-year } \\
\text { exposure } \\
(\% / 0)\end{array}$ \\
\hline Better pay & 38 & 30 \\
Better prospects & 19 & 15 \\
Better work conditions & 31 & 31 \\
Less physically demanding & 31 & 30 \\
Only possibility & 13 & 12 \\
Trained for new occupation & 21 & 9 \\
Work more interesting & 39 & 32 \\
Others & 14 & 19 \\
\hline
\end{tabular}

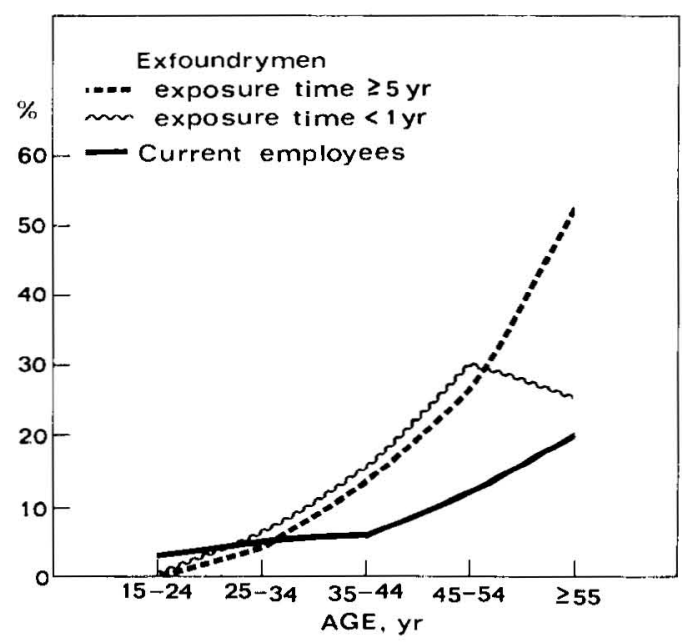

Fig. 3. Percentages of current and former foundrymen who felt themselves to be in poor hoalth versus age.



Fig. 4. Percentages of current and former foundrymen who felt their work capacity was poor. ( 0 to 4 points on a 10-point scale)

Health differences between current and former workers

General. A general picture of the difference in health between current and former foundrymen can be had from their own assessments of their current state of health. Significantly more of the exfoundrymen - both 5-year-plus (Mantel \& Haenszel: $p<0.01$ ) and 1-year-minus $(p<$ 0.001) - felt they were ill than did the current employees. A similar difference has been found in corresponding replies from former and current dock workers (2). Fig. 3 shows that the difference appeared mainly in the older age classes.

The difference in work capacity (fig. 4) between the exfoundrymen (both exposure classes) and the current workers indicates that foundry work tends both to weed out those with a poor work capacity at an early stage (1-year-minus men) and weaken the work capacity of the healthier (5-year-plus) men in the course of time. This supposition was borne out by a regression analysis on work capacity. The 
analysis took into account whether the "best working age" occurred before or after the start of foundry work, the changes in work capacity during foundry work, and the changes in work capacity after leaving the foundry. It was applied to current workers and to the 5-year-plus former workers. The only sure finding for the current workers was a steady fall in work capacity with age. Similarly with the 5-year-plus men whose "best working age" occurred before they began foundry work, it could only be established that their work capacity fell with age during this work. However in the case of the 5 -year-plus men, whose best working age occurred after they began foundry work, there was a clear drop in work capacity while they were at the foundry. Their best working age (10 points) averaged 28 years, but their work capacity dropped to an average of 6.1 points by the time they turned 37 (the average quitting age). After they left, their average work capacity rose again slightly and then dropped steadily with age, but it did so far more slowly than it had while they were at the foundry (fig. 5).

The result shows that foundry work has a very strong selective effect. Only men with a better than average work capacity stay in foundry work for a long time. Not only that, the health selection often starts before workers enter foundry work, most newcomers being men who feel themselves to be healthy (those whose best working age occurred before they came to the foundry). The fact that persons who leave physically demanding work become more fit to work after doing so has been noted earlier (1). There are two main reasons for this: (a) their work capacity rises on the point scale because the new work is easier

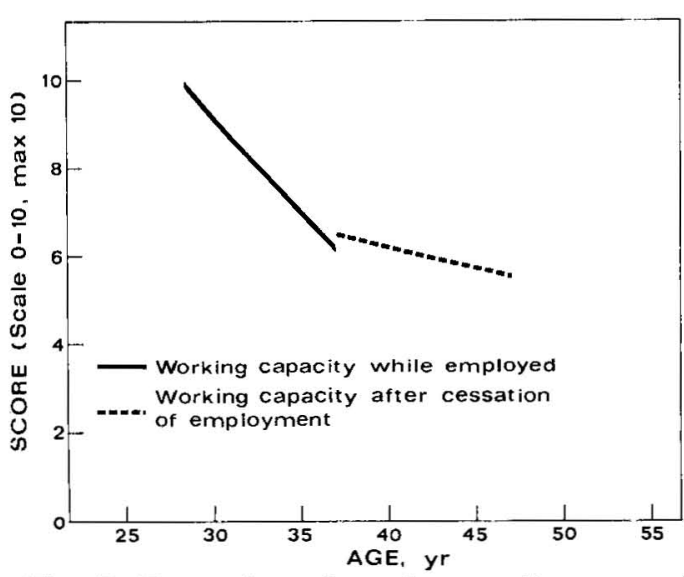

Fig. 5. Regression of work capacity assessed by exfoundrymen with 5 or more years of exposure.

Table 14. Exfoundrymen on disability pensions (observed) as of 31 December 1972 in comparison with the number expected, based on the Finnish male population (excluding persons pensioned before reaching working age).

\begin{tabular}{|c|c|c|c|c|c|c|}
\hline \multirow{2}{*}{ Age (a) } & \multicolumn{2}{|c|}{$<$ 1-year exposure } & \multicolumn{2}{|c|}{ 3- to 4.9-year exposure } & \multicolumn{2}{|c|}{$\geq$ 5-year exposure } \\
\hline & Observed & Expected & Observed & Expected & Observed & Expected \\
\hline $16-34$ & 3 & 3.2 & 5 & 2.1 & 1 & 4.4 \\
\hline $35-44$ & 9 & 5.5 & 0 & 3.7 & 5 & 7.6 \\
\hline $45-54$ & 10 & 13.7 & 7 & 9.0 & 25 & 19.0 \\
\hline $55-64$ & 7 & 29.6 & 7 & 19.5 & 25 & 40.8 \\
\hline Total & 29 & 52.0 & 19 & 34.3 & 56 & 71.8 \\
\hline
\end{tabular}

Table 15. Age-standardized occurrences $(\%)$ of diseases notified by the current and former foundrymen as being due to foundry work.

\begin{tabular}{|c|c|c|c|c|c|}
\hline Foundrymen & $\begin{array}{c}\text { One or } \\
\text { more } \\
\text { disease }\end{array}$ & $\begin{array}{l}\text { Two or } \\
\text { more } \\
\text { diseases }\end{array}$ & $\begin{array}{l}\text { Lung } \\
\text { disease }\end{array}$ & $\begin{array}{l}\text { Cardio- } \\
\text { vascular } \\
\text { disease }\end{array}$ & $\begin{array}{l}\text { Musculo- } \\
\text { skeletal } \\
\text { disease }\end{array}$ \\
\hline Current & 52 & 16 & 11 & 4 & 20 \\
\hline $\begin{array}{l}<1 \text {-year exposure } \\
\geq 5 \text {-year exposure }\end{array}$ & $\begin{array}{l}15 \\
48\end{array}$ & $\begin{array}{r}4 \\
13\end{array}$ & $\begin{array}{r}4 \\
13\end{array}$ & $\begin{array}{l}1 \\
5\end{array}$ & $\begin{array}{r}7 \\
24\end{array}$ \\
\hline
\end{tabular}


and/or (b) their new work conditions preserve or improve their work capacity.

The Social Insurance Register gives a different picture. On 31 December 1972, 6.7 \% of all men aged 16 to 64 were receiving disability pensions, whereas the age-standardized disability prevalence of our foundrymen was only $5.1 \%$ for the 1-yearminus men and $4.0 \%$ for the 5-year-plus men. Therefore the prevalence of the 3- to 5-year exposure class was calculated as a check and found to be only $4.8 \%$.

Table 14 shows the number of exfoundrymen with disability pensions compared to the expected number based on the Finnish male population. The latter does not include persons who were disabled before reaching a working age. Also adjusted are certain differences due to the divergent age structure of the foundrymen. Despite these adjustments disabled men were clearly less frequent among foundry workers than among the male population.

Health differences between the former and current foundrymen can also be seen in the varying prevalences of certain diseases and symptoms. About half of the current workers and 5-year-plus exfoundrymen believed that foundry work had caused them to have at least one disease. This ratio corresponds well to replies given to the same question by granite workers (1). Naturally the ratio was smaller for the 1-year-minus men, whose exposure was shorter. Table 15 shows the agestandardized occurrences of diseases considered by the foundrymen to be due to foundry work.

Data from the current and 5-year-plus former men were analyzed with a Mantel \& Haenszel test, but the difference between them was not statistically significant for any disease.

Respiratory diseases. Chronic bronchitis was clearly associated with exposure to dust among the current foundrymen (7). For the exfoundrymen, too, the prevalence of bronchitis was greater among those formerly in dusty work than among those in other occupations (table 16), but the differences were not statistically significant.

The frequency of chronic bronchitis was similar among the current and former foundrymen, but age class breakdowns revealed differences between them (table 17). The high prevalence among the 5 -year-plus men aged 55 to 64 years suggests that chronic bronchitis caused them to leave foundry work before reaching the normal age of retirement (65 years in Finland).

The age-standardized occurrences of diagnosed lung diseases were higher among the former than among the current workers (table 18). Silicosis was reported by $3.8 \%$ (13 cases) of the 5-yearplus exfoundrymen, but this percentage did not. 
Table 17. Prevalences (\%) of chronic bronchitis per age class among current and former foundrymen.

\begin{tabular}{|c|c|c|c|c|c|c|c|}
\hline \multirow{2}{*}{ Foundrymen } & \multicolumn{6}{|c|}{ Age (a) } & \multirow{2}{*}{ Total } \\
\hline & $15-24$ & $25-34$ & $35-44$ & $45-54$ & $55-64$ & $\geq 65$ & \\
\hline $\begin{array}{l}\text { Current } \\
\text { Former }\end{array}$ & 6 & 15 & 16 & 18 & 13 & 0 & 16 \\
\hline$<1$-year exposure & 0 & 6 & 17 & 17 & 11 & 0 & 10 \\
\hline$\geq 5$-year exposure & 0 & 9 & 11 & 17 & 35 & 10 & 15 \\
\hline
\end{tabular}

differ significantly from the $2.6 \%$ prevalence notified by the current workers who underwent the health examination. Lung tuberculosis and/or pleuritis were significantly more prevalent among both the 1-year-minus and the 5-year-plus exfoundrymen than among the current workers (Mantel \& Haenszel: p < 0.01). Emphyse$\mathrm{ma}$, bronchitis, and bronchial asthma were all more frequent among former workers than current ones. The age-specific combined prevalences of these diseases were similar to that of chronic bronchitis. The prevalence among the 5-year-plus men was statistically higher (Mantel \& Haenszel: $\mathrm{p}<0.01)$ than among the current workers, the difference becoming accentuated in the 55- to 64-year age class.

The number of men with disability pensions due to respiratory diseases among all the exposure classes studied was lower or roughly equal to the expected number based on the male population.

Cardiovascular diseases. Eleven per cent of the current workers notified an earlier diagnosis of high blood pressure. The prevalence was significantly greater (Mantel \& Haenszel: $p<0.01$ ) among the 5year-plus exfoundrymen; in the highest age classes (55 years and more) it was over three times greater than among the current workers. The hypertension prevalence for the 1-year-minus men was roughly the same as for the current workers (table 19).

Similarly, diagnosed heart disorders were significantly more prevalent (Mantel \& Haenszel: $\mathrm{p}<0.05$ ) among the former, both 1-year-minus and 5-year-plus, workers than among the current foundrymen (table 20).

There was little difference in the prevalence of angina pectoris among the former workers of the two exposure classes and the current foundrymen (table 21). The combined prevalence of mild or severe angina pectoris and/or severe chest pains lasting half an hour or more and/or diagnosed heart disorders was $20 \%$ for the current workers, $23 \%$ for the 1-yearminus men, and $30 \%$ for the 5-year-plus men (fig. 6). The age-standardized prevalence of this combination was $37 \%$ among the 1-year-minus men formerly in $\mathrm{CO}$ exposed iron foundry occupations and $28 \%$ among those in the other iron foundry occupations. Among the 5-year-plus men the prevalence was $33 \%$ for those in the $\mathrm{CO}$ exposed and other occupations alike in the iron foundries; in the steel and nonferrous foundries the prevalence was $17 \%$ for those workers in the $\mathrm{CO}$ exposed occupations and $27 \%$ for those in all other work. It should be pointed out that these foundry prevalences were based on very small figures.

When the former workers and the current workers who took the health examination were asked the reason for their latest visit to a doctor, $6 \%$ of the current workers notified cardiovascular diseases. This percentage was clearly less than that found in a polling inquiry of the male population of Finland (14). Circulatory diseases were the reason for the latest visit to a physician for only $2 \%$ of the current foundrymen under 35 years of age, and for $8 \%$ of those over 35 years. The results were roughly the same for the 5year-plus exfoundrymen, and also for the 1-year-minus men under 35 years of age. However $14 \%$ of the 1-year-minus men above this age gave diseases of the circulatory system as the reason for their latest visit to a doctor.

Cardiovascular diseases were the reason for relatively fewer disability pensions among the exfoundrymen than among the male population of the same age. The same was found when the age-specific 


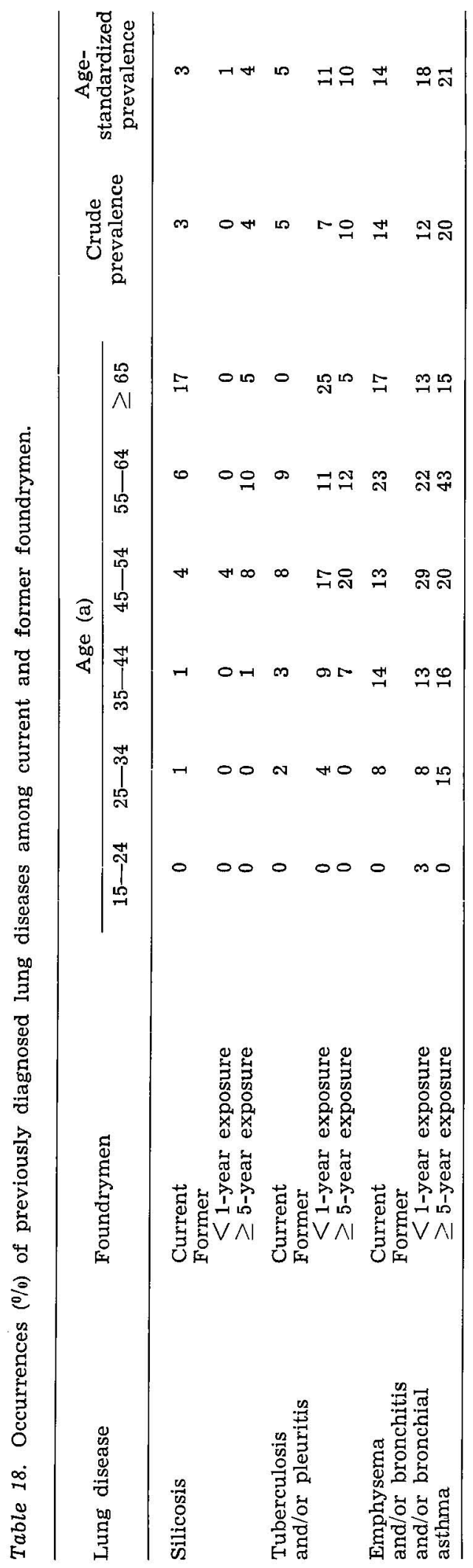

disability rates were analyzed for the exposure classes.

Musculoskeletal diseases. Musculoskeletal stress was indicated by the reasons given for leaving foundry work and choosing a new occupation. It was borne out by replies to the question on postures at work. Fatiguing and uncomfortable postures were clearly more prevalent among the current workers than among the former foundrymen in their new occupations (table 22).

Musculoskeletal diseases accounted for $14 \%$ of the reasons for the latest visit to a doctor among the current workers and 1-year-minus exfoundrymen, and 18 $\%$ among the 5-year-plus men. These percentages were clearly higher than those found in a polling inquiry of the Finnish male population (14). However, the proportion of foundrymen receiving disability pensions due to musculoskeletal diseases did not exceed that in the male population of the same age. This result seems to confirm that musculoskeletal stress causes health selection before disability pensions come into question.

\section{DISCUSSION}

The turnover among the foundrymen was very quick. It was due both to fluctuations in the business cycle and to health selection. The turnover among the 1-yearminus men (exfoundrymen who had been exposed to foundry work for less than a year) was due mainly to better job opportunities. But here, too, health selection was involved. Those who found the work unsuitable left it, and therefore the observed prevalence of diseases and symptoms was raised among the former workers of this exposure class. Health selection was clearly a more important reason for the turnover of the 5-year-plus men.

All in all, rapid turnover makes it difficult to measure the effect of work on health because the level of the effect cannot be predicted. Furthermore, some health selection presumably occurs even before work is started.

The termination-of-employment rate was fastest among the youngest age classes, and it decreased with age. The renewed rise of the rate in the 50- to 54-year class was due mainly to growing morbidity caused by the longer exposure. The num- 
Table 19. Diagnosed hypertension $(\%)$ per age class of current and former foundrymen.

\begin{tabular}{lrrr}
\hline & & \multicolumn{2}{c}{ Former } \\
\cline { 3 - 4 } Age (a) & Current & $\begin{array}{c}<\text { 1-year } \\
\text { exposure }\end{array}$ & $\begin{array}{c}\geq \text { 5-year } \\
\text { exposure }\end{array}$ \\
\hline $15-24$ & 0 & 3 & 0 \\
$25-34$ & 7 & 9 & 15 \\
$35-44$ & 9 & 17 & 13 \\
$45-54$ & 14 & 13 & 28 \\
$55-64$ & 17 & 22 & 30 \\
$\geq 65$ & 0 & 0 & 60 \\
\hline Total & 11 & 12 & 22 \\
\hline
\end{tabular}

ber of questionnaire respondents who felt their work capacity to be low clearly rose at this age among the former workers; so too did the number of multiple symptoms. There was also a clear upswing in the frequency of disability pensions starting at this age. Similarly mortality, compared to the expected value, was highest at this age.

Relatively speaking, illness or disability was notified as the reason for leaving four times more often by the 5-year-plus men than by 1-year-minus men. Among those who took nonfoundry jobs, better work conditions and less physically demanding work were the predominant motives. The preference for lighter work was also

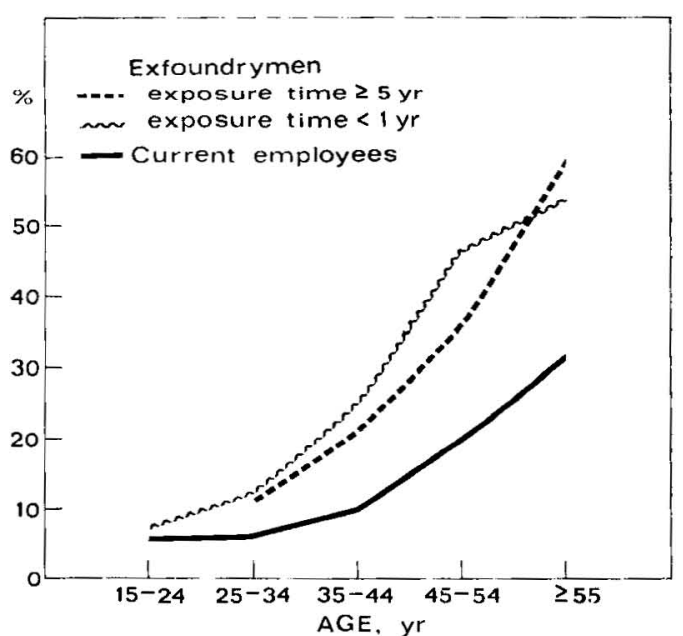

Fig. 6. Combined positive histories $(\%)$ of mild or severe angina pectoris and/or severe chest pains lasting half an hour or more and/or heart disorders versus age.

visible in the jobs the exfoundrymen obtained after quitting the foundry; light industry predominated. In all, $32 \%$ of the 5-year-plus men found jobs in nonfoundry industries. One-quarter of the 1-year-minus men went into the construction industry and a quarter entered nonfoundry industries.

The shift in occupations was partly due to changes in the occupational structure

Table 20. Age-standardized occurrences $(\%)$ of previously diagnosed heart disorders among current and former foundrymen.

\begin{tabular}{|c|c|c|c|c|c|}
\hline Foundrymen & $\begin{array}{l}\text { Any heart } \\
\text { disorder }\end{array}$ & $\begin{array}{l}\text { Valvular } \\
\text { disease }\end{array}$ & $\begin{array}{c}\text { Myocardial } \\
\text { insuffici- } \\
\text { ency }\end{array}$ & $\begin{array}{l}\text { Coronary } \\
\text { infarction }\end{array}$ & $\begin{array}{c}\text { Abnormal } \\
\text { ECG } \\
\text { findings }\end{array}$ \\
\hline $\begin{array}{l}\text { Current } \\
\text { Former }\end{array}$ & 15 & 1 & 4 & 1 & 4 \\
\hline $\begin{array}{l}\geq 5 \text {-eyar exposure } \\
<1 \text {-year exposure }\end{array}$ & $\begin{array}{l}21 \\
24\end{array}$ & $\begin{array}{l}2 \\
2\end{array}$ & $\begin{array}{r}7 \\
10\end{array}$ & $\begin{array}{r}5 \\
10\end{array}$ & $\begin{array}{l}6 \\
6\end{array}$ \\
\hline
\end{tabular}

Table 21. Prevalences (\%) of angina pectoris per age class among current and former foundrymen.

\begin{tabular}{|c|c|c|c|c|c|c|c|c|}
\hline \multirow{2}{*}{ Foundrymen } & \multicolumn{6}{|c|}{ Age (a) } & \multirow{2}{*}{$\begin{array}{c}\text { Crude } \\
\text { prevalence }\end{array}$} & \multirow{2}{*}{$\begin{array}{c}\text { Age- } \\
\text { standardized } \\
\text { prevalence }\end{array}$} \\
\hline & $15-2$ & -34 & $35-4$ & $5-5$ & $5-64$ & $\geq 65$ & & \\
\hline \multirow{2}{*}{$\begin{array}{l}\text { Current, unexposed } \\
\text { to carbon monoxide } \\
\text { Former } \\
>\text { 1-year exposure } \\
>\text { 5-year exposure }\end{array}$} & 0 & 5 & 9 & 15 & 24 & 20 & 12 & 12 \\
\hline & $\begin{array}{r}0 \\
25\end{array}$ & $\begin{array}{l}4 \\
2\end{array}$ & $\begin{array}{l}8 \\
8\end{array}$ & $\begin{array}{l}38 \\
15\end{array}$ & $\begin{array}{l}11 \\
26\end{array}$ & $\begin{array}{l}25 \\
25\end{array}$ & $\begin{array}{r}9 \\
12\end{array}$ & $\begin{array}{l}16 \\
12\end{array}$ \\
\hline
\end{tabular}


Table 22. Uncomfortable postures $(6 \mathrm{~h} /$ work shift) used by current and former foundrymen in their current occupations.

\begin{tabular}{lccc}
\hline Posture & Current & \multicolumn{2}{c}{ Former foundrymen } \\
\cline { 3 - 4 } & foundrymen & $\begin{array}{c}<1 \text {-year } \\
\text { exposure }\end{array}$ & $\begin{array}{r}\geq 5 \text {-year } \\
\text { exposure }\end{array}$ \\
\hline Standing & 83 & 48 & 55 \\
Crouching & 41 & 20 & 19 \\
Lifting heavy weights manually & 23 & 18 & 16 \\
Working with arms raised & 18 & 15 & 11 \\
Working with body twisted & 17 & 6 & 7 \\
Carrying heavy objects & 11 & 7 & 2 \\
Kneeling & 2 & 1 & 7 \\
\hline
\end{tabular}

of Finland. Even so, the demand for lighter work was greater than the supply. Among those who moved on to another foundry, one-third of the 5-year-plus men and one-fifth of the 1-year-minus men said they did so because it was the only work they could get. The early shift towards less physically demanding and/or less exposed (dust, CO or other) occupations was also reflected by the fact that the prevalence of disability pensions among exfoundrymen was smaller than among the Finnish male population. There was not even a greater prevalence due to musculoskeletal diseases, which have been found to increase disability figures in other physically demanding trades (1).

The termination-of-employment rate was significantly higher in the dusty occupations than in the others. The termination was due partly to the unpleasantness of dust and partly to health selection proper. On the whole, diseases of the respiratory system had only a slight selective effect during foundry work because of the long exposure and/or induction times required. In this case the health selection mainly took the form of a higher prevalence of diagnosed lung disease (emphysema, bronchitis, bronchial asthma, lung tuberculosis and pleuritis) among former than among current employees. However the prevalence of chronic bronchitis was roughly the same for current workers as for former workers - except for the 5 -year-plus men aged 55 to 64 years, among whom it was significantly higher than among the current workers of the same age.

Health selection had a clearer effect in the case of heart diseases. The questionnaires revealed a significantly greater number of men in the $\mathrm{CO}$ exposed occupations among the 5-year-plus former workers than among the current employees. Pair comparison gave similar results. Generally speaking, there were more heart diseases diagnosed among former than among current employees. The prevalences were the highest for the 1-yearminus men and they indicated a very rapid selective effect on men previously suffering from or prone toward heart diseases. On the other hand the former and current employees did not differ much in their angina pectoris prevalences. The combined prevalence of diagnosed heart disorders and/or chest pains lasting half an hour or more and/or angina pectoris was somewhat higher among the 1-yearminus men formerly engaged in $\mathrm{CO}$ exposed occupations in iron foundries than among the other 1-year-minus men or the 5-year-plus men as a whole. The numbers involved in this comparison, however, were too small for any definite conclusions to be drawn.

The selective effect of heart maladies among the 1-year-minus men was also suggested by the number of visits to a doctor due to cardiovascular diseases among the men over 35 years of age in this exposure class; the number was relatively higher than in the case of the current employees and 5-year-plus exfoundrymen of the same age. In regard to heart diseases among foundrymen, the health selection findings appear to have an extra explanatory value for the results of both the health examination (6) and the mortality study (9) of the Finnish Foundry Project.

In this study turnover was analyzed with a method somewhat different from that 
used in most turnover studies because the aim of the study was to reveal the effects of foundry work on health. Therefore it was only necessary to study turnover inasmuch as it confused the reliable measurement of the effects on health. In this respect the turnover analysis fulfilled its purpose well. It gave some idea of the underestimation produced by a purely cross-sectional study of morbidity. To some extent it explained the apparent anomalies in the disability and mortality figures. The selectivity of the turnover proved to be a major explanatory factor in measuring the effects of foundry work on health.

\section{ACKNOWLEDGMENTS}

The authors wish to thank Ms. Raija Vuorela and Ms. Hilkka Tiainen for their assistance in carrying out the questionnaire study and coding the data and Ms. Eira Böhm for assisting in the calculation of turnover rates. Our thanks are also due to Erkki Järvinen, M.Sc., for his statistical advice during this study, Ms. Pirjo Fahlström for programing the data analysis, and Ms. Marja-Liisa Korkala for drawing the figures.

\section{REFERENCES}

1. AHLMAN, K., BACKMAN, A.-L., HANNUNKARI, I., JÄRVINEN, E., KOPONEN, M., KOSKELA, R.-S., PARTANEN, T., SEPPÄLÄINEN, A. M. and STARCK, J. Kivityöntekijöiden työolosuhteet ja terveydentila [Work conditions and health of granite workers] (Kansaneläkelaitoksen julkaisuja AL: 4/1975) Social Insurance Institution, Helsinki 1975. 128 p. (English summary)

2. AHLMAN, K., BACKMAN, A.-L., KOSKELA, R.-S. and LUOMA, K. Satamatyöntekijöiden työolot ja terveydentila [The health and work conditions of dock workers] (Työterveyslaitoksen tutkimuksia no. 105). Institute of Occupational Health, Helsinki 1975. 64 p. (English summary)

3. GOLDSMITH, J. R. What do we expect from an occupational cohort? J. occup. med. 17 (1975) 126-127.

4. HÄKKINEN, I. Byssinoosi Suomen puuvillateollisuudessa [Byssinosis in the Finnish cotton industry] (Työterveyslaitoksen tutkimuksia no. 121). Institute of Occupational Health, Helsinki 1975. 99 pp. (Doctoral dissertation - English summary)

5. HERNBERG, S. The Finnish foundry project: Background and general method- ology. Scand. j. work environ. \& health 2 (1976): suppl. 1, 8-12.

6. HERNBERG, S., KÄAVA, R., KOSKELA, R.-S. and LUOMA, K. Angina pectoris, ECG findings and blood pressure of foundry workers in relation to carbon monoxide exposure. Scand. j. work environ. \& health 2 (1976): suppl. 1, 54-63.

7. KÄRÄVÄ, R., HERNBERG, S., KOSKELA, R.-S. and LUOMA, K. Prevalence of pneumoconiosis and chronic bronchitis in foundry workers. Scand. j. work environ. \& health 2 (1976): suppl. 1, 64-72.

8. KANSANELÄKELAITOS. Kansaneläkelaitoksen tilastollisia vuosikatsauksia 1972 , 1974 [Social Insurance Institution's statistical review 1972, 1974]. (Kansaneläkelaitoksen julkaisuja T3:3C). Helsinki 1975. $54 \mathrm{p}$.

9. KOSKELA, R.-S., HERNBERG, S., KÄRÄVÄ, R., JÄRVINEN, E. and NURMINEN, M. A mortality study of foundry workers. Scand. j. work environ. \& health 2 (1976): suppl. 1, 73-89.

10. MANTEL, N. and HAENSZEL, W. Statistical aspects of the analysis of data from retrospective studies of disease. $J$. natl. cancer inst. 22 (1959) 719-748.

11. MC MICHAEL, A. J., SPIRTAS, R. and KUPPER, L. L. An epidemiologic study of mortality within a cohort of rubber workers, 1964-1972. J. occup. med. 16 (1974) 458-464.

12. MEDICAL RESEARCH COUNCIL'S COMMITTEE ON AETIOLOGY OF CHRONIC BRONCHITIS. Standardized questionnaires on respiratory symptoms. Brit. med. j. 2 (1960) 1665.

13. PAFFENBARGER, R. S. JR., LAUGHLIN, M. E., GIMA, A. S. and BLACK, R. A. Work activity of longshoremen as related to death from coronary heart disease and stroke. New engl. j. med. 282 (1970) 1109 1114.

14. PUROLA, T., NYMAN, K., KALIMO, E. and SIEVERS, K. Sairausvakuutus, sairastavuus ja lääkintäpalvelusten käyttö [Sickness insurance, morbidity and the use of medical services] (Kansaneläkelaitoksen julkaisuja, sarja A:7). Sosiaaliturvan tutkimuslaitos, Helsinki 1971. 493 p.

15. ROSE, G. A. and BLACKBURN, H. Cardiovascular survey methods. World Health Organization, Geneva 1968. 188 p.

16. TILASTOKESKUS. Kansantalouden tilinpito [National accounting 1964-1974/III]. Helsinki 1974. $104 \mathrm{p}$.

17. TILASTOLLINEN PÄÄTOIMISTO. SUomen kansantalouden tilinpito vuosina 1948 -1964: Taulut [National accounting in Finland in 1948-1964: Tables] Helsinki 1968. $106 \mathrm{p}$.

18. WICKSTROM, G. and KAUPPINEN-TOROPAINEN, K. Rakennusalan työntekijöiden työolot ja terveydentila: Kyselytutkimus [The work conditions and health of construction workers: A questionnaire study] (Työterveyslaitoksen tutkimuksia no. 91) Institute of Occupational Health Helsinki 1974. 154 p. (English summary) 